\title{
Emission, distribution and toxicity of polycyclic aromatic hydrocarbons (PAHs) during municipal solid waste (MSW) and coal co-combustion
}

\author{
Nana Peng ${ }^{\mathrm{a}, \mathrm{b}}, \mathrm{Yi} \mathrm{Li}^{\mathrm{c}}$, Zhengang Liu ${ }^{\mathrm{a}, \mathrm{b}, *}$, Tingting Liu ${ }^{\mathrm{a}, \mathrm{b}}$, Chao Gai ${ }^{\mathrm{a}, \mathrm{b}}$ \\ ${ }^{a}$ Research Center for Eco-Environmental Sciences, Chinese Academy of Sciences, Beijing 100085, China \\ ${ }^{\mathrm{b}}$ University of Chinese Academy of Sciences, Beiijing 100049, China \\ c State Key Laboratory of Multiphase Complex Systems, Institute of Process Engineering, Chinese Academy of Sciences, Beijing 100190, PR China
}

\section{H I G H L I G H T S}

- Emission characteristics of PAHs were investigated during MSW/coal co-combustion.

- Compare to coal, more PAHs were generated during MSW combustion.

- Significant interactions were observed between coal and MSW during co-combustion.

- The interactions suppressed the PAHs formation, especially hazardous highring PAHs.

- The interactions reduced the toxicity of PAH emissions during co-combustion.

\section{G R A P H I C A L A B S T R A C T}

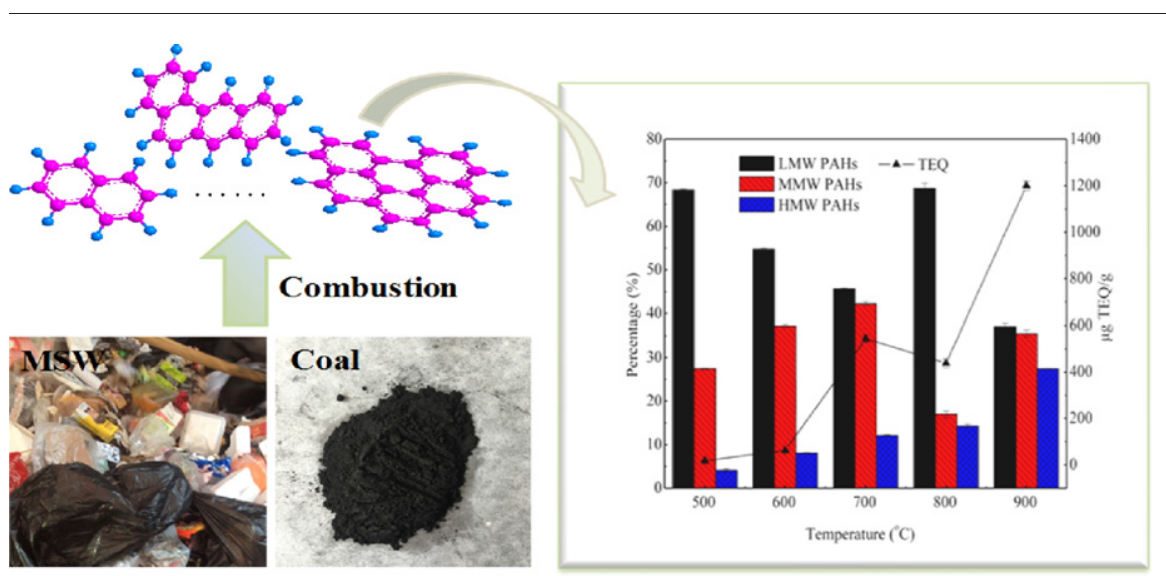

\section{A R T I C L E I N F O}

\section{Article history:}

Received 11 April 2016

Received in revised form 26 May 2016

Accepted 26 May 2016

Available online 2 June 2016

Editor: Jay Gan

\section{Keywords:}

Flue gas

Bottom ash

Fly ash

Synergistic interaction

PAHs

\begin{abstract}
A B S T R A C T
Emission and distribution characteristics of polycyclic aromatic hydrocarbons (PAHs) were investigated during municipal solid waste (MSW) and coal combustion alone and MSW/coal blend (MSW weight fraction of 25\%) co-combustion within a temperature range of $500{ }^{\circ} \mathrm{C}-900{ }^{\circ} \mathrm{C}$. The results showed that for all combustion experiments, flue gas occupied the highest proportion of total PAHs and fly ash contained more high-ring PAHs. Moreover, the 3- and 4-ring PAHs accounted for the majority of total PAHs and Ant or Phe had the highest concentrations. Compared to coal, MSW combustion generated high levels of total PAHs with the range of $111.28 \mu \mathrm{g} / \mathrm{g}-10,047.22 \mu \mathrm{g} / \mathrm{g}$ and had high toxicity equivalent value (TEQ). MSW/coal co-combustion generated the smallest amounts of total PAHs and had the lowest TEQ than MSW and coal combustion alone. Significant synergistic interactions occurred between MSW and coal during co-combustion and the interactions suppressed the formation of PAHs, especially hazardous high-ring PAHs and decreased the TEQ. The present study indicated that the reduction of the yield and toxicity of PAHs can be achieved by co-combustion of MSW and coal.
\end{abstract}

(c) 2016 Elsevier B.V. All rights reserved.

\footnotetext{
* Corresponding author at: 18 Shuangqing Road, Beijing 100085, PR China. E-mail address: zgliu@rcees.ac.cn (Z. Liu).
}

\section{Introduction}

China has experienced an unprecedented increase in the amount of municipal solid waste (MSW) in recent years due to the population 
growth, rapid urbanization and industrialization (Zhou et al., 2015). It is reported that the amount of MSW is increasing at an annual rate of 8$10 \%$ and had grown to 173 million tons in 2013 (Cheng and $\mathrm{Hu}$, 2010). Therefore, the disposal of MSW is a major and urgent problem that must be solved. Generally, there are three methods for MSW disposal: landfill, composting and incineration. Of these methods, incineration has received considerable attention as a promising method for effective energy recovery, significant volume reduction (by up to $70 \%$ in weight and $90 \%$ in volume) and high degree detoxicity (Tian et al., 2012). However, some inherent properties of MSW such as high moisture content and low calorific value are the main drawbacks associated with MSW incineration (Singh et al., 2011) and as a result, MSW combustion has low thermal efficiency and relatively high pollutant emissions. To overcome these problems, co-combustion of MSW and coal has turned out to be an effective and economical option as addition of coal to MSW not only can increase the calorific value but also effectively buffer the impact of the variation of MSW quality on combustion process. Extensive studies related to MSW/coal co-combustion have been carried out over the years (Muthuraman et al., 2010a, 2010b; Suksankraisorn et al., 2010). For example, Suksankraisorn et al. studied the emissions of $\mathrm{CO}, \mathrm{NO}_{\mathrm{x}}$ and $\mathrm{SO}_{2}$ during MSW/lignite cocombustion and found that the synergistic effect between lignite and MSW increased combustion efficiency and reduced CO emission (Suksankraisorn et al., 2010). Additionally, a thermogravimetric analysis of MSW and Indian coal co-combustion was carried out and the results showed that a homogeneous combustion for MSW/coal blend was similar to that of the coal by up to 20\% MSW blend (Muthuraman et al., 2010a).

PAHs are a group of ubiquitous and widespread semi-volatile hydrocarbons and many PAHs are carcinogenic, teratogenic and mutagenic (Pongpiachan et al., 2015; Ribeiro et al., 2012; Wang et al., 2015). The main sources of PAHs are the pyrolysis or incomplete combustion of carbon containing fuels such as coal, petroleum and biomass (MugicaAlvarez et al., 2015). Hence, as a huge energy consumer, PAH emissions are very serious in China and approximately $62 \%$ of total PAHs were generated from solid fuel combustion (Xu et al., 2006; Zhang et al., 2007). Emission standards are becoming increasingly stringent for $\mathrm{PAH}$ emissions to minimize their environmental impact in China nowadays.

Numerous studies have appeared related to PAH emissions from coal combustion. For instance, Liu et al. investigated emission characteristics of PAHs from six coals in North China and found that the total risk of toxicity of anthracite coal was lower than that of bituminous coal (Liu et al., 2009). Meanwhile, the PAH contents of coal and its combustion residues from a power plant were investigated and the results showed that the total PAHs in raw coal was much higher than that in fly ash and bottom ash (Verma et al., 2015). In addition, some studies also investigated the formation of PAHs during MSW combustion. Zhang et al. determined the amount of PAHs in fly ash samples collected from a MSW incinerator and found that 3- and 4- ring PAHs were the principal constituents of PAHs (Zhang et al., 2014). Similarly, the bottom ash obtained from a MSW incinerator was analyzed and the results showed that the patterns of PAHs were also dominated by 3- and 4- ring PAHs (Shen et al., 2010).

To our best knowledge, PAH emissions during MSW/coal co-combustion have not yet been studied in detail. With the increasing importance of MSW/coal co-combustion, understanding the emission and distribution of PAHs is urgent for its large-scale application. In the present study, MSW/coal co-combustion was conducted on a laboratory scale tubular furnace and the main objective of this study is to 1) determine the effect of combustion temperature on PAH emissions during MSW and coal combustion alone and their co-combustion, 2) investigate the distribution of PAHs in flue gas, fly ash and bottom ash, and 3) evaluate the influence of the blending of MSW and coal on PAH emissions and distribution.

\section{Materials and methods}

\subsection{Materials}

Bituminous coal used in this study was obtained from a coal mine in Inner Mongolia, China. To make the MSW more representative, the modified MSW sample was used in the present study. A modified MSW sample was comprised of food residue (64.93\%), wood waste (1.48\%), paper (12.94\%), textiles (3.11\%), plastics (15.07\%) and noncombustibles (2.47\%) based on the literature and field research in Beijing, China (Zhou et al., 2014). Polyvinyl chloride was used to represent the plastics due to its high fraction in MSW in China (Shen et al., 2010; Yu et al., 2016). Food waste, wood waste and textiles were collected from a canteen and refuse collection station of a university, respectively. All samples were dried at $105^{\circ} \mathrm{C}$ for $24 \mathrm{~h}$ and milled to around 80 mesh particles before use, except for paper and textiles that were cut into $1 \mathrm{~cm}$ in diameter. The blending of coal and MSW was prepared as the coal weight fraction of 75\% (Liu et al., 2013; Muthuraman et al., 2010a). A Vario MACRO cube Elemental Analyzer was used to determine the carbon, hydrogen, sulfur and nitrogen contents of samples. The combustion temperature was $1150{ }^{\circ} \mathrm{C}$ and the carrier gas was helium. The analyte gases including $\mathrm{CO}_{2}, \mathrm{SO}_{2}, \mathrm{NO}_{2}$ and $\mathrm{H}_{2} \mathrm{O}$, was separated and analyzed by a detector (TCD) after decreasing the formation of $\mathrm{NO}_{2}$ at $850{ }^{\circ} \mathrm{C}$. The proximate analysis was obtained by the standard practice for the Proximate Analysis of coal (GB/T212-2008). The ash contents are calculated as the weight loss ratio after combustion at $815 \pm 10^{\circ} \mathrm{C}$. The volatile matter content was calculated by the weight loss ratio subtracting the moisture content from the initial weight at $900 \pm 10^{\circ} \mathrm{C}$ under dry $\mathrm{N}_{2}$ atmosphere. The fixed carbon content was defined as the difference ( 100 - ash content - volatile matter content). Proximate and ultimate analysis results of the coal and MSW are presented in Table 1.

\subsection{PAHs sampling and analysis}

Fig. S1 showed the schematic diagram of the experimental setup and PAHs collection methods. All combustion experiments were conducted on a laboratory scale tubular furnace (55 $\mathrm{mm}$ i.d., $100 \mathrm{~cm}$ long), a frequently used reaction equipment for analyzing the emission and distribution of PAHs during fuel combustion (Dong et al., 2012; Liu et al., 2012). The sample (around $1 \mathrm{~g}$ ) was placed into a quartz boat and then inserted into the horizontal quartz reactor tube in air atmosphere when the temperature reached its desired value. The flow rate of air gas was $500 \mathrm{ml} / \mathrm{min}$ and the residence time was $30 \mathrm{~min}$ (Yan et al., 2004). The PAHs in fly ash were collected by quartz fiber filters (QFFs) (Tsai et al., 2010). In the case of PAHs in flue gas, it was determined by the adsorption method. The gas outlet was linked to a set of absorption apparatus that was composed of a tube filled with XAD-2 and two bottles of dichloromethane (DCM) which were placed in ice baths. The bottom ash was designated as the residue in the quartz boat. After complete combustion and cooling down to room temperature, the bottom ash, QFFs, XAD-2 and absorption liquid were analyzed for PAHs.

Table 1

Ultimate and proximate analysis of MSW and coal used in the present study.

\begin{tabular}{lrr}
\hline & MSW & Coal \\
\hline Ultimate analysis (\%, daf) & & \\
C & 42.13 & 66.41 \\
H & 6.92 & 3.84 \\
N & 1.55 & 0.74 \\
S & 0.29 & 0.48 \\
Proximate analysis (\%, db) & & \\
Volatile matter & 86.94 & 26.43 \\
Ash & 3.16 & 11.67 \\
Fixed carbon & 9.90 & 61.90 \\
\hline
\end{tabular}


The surrogate standard solution containing naphthalene- $\mathrm{d}_{8}$, chrysene- $d_{12}$, perylene- $d_{12}$, acenaphthene- $d_{10}$ and phenanthrene- $d_{10}$ was firstly added to XAD-2 and absorption liquid and then they were extracted in a Soxhlet extractor with DCM for $24 \mathrm{~h}$ (Dai et al., 2014). The extract was concentrated to $1 \mathrm{ml}$ by a rotary evaporator, followed by transforming the solvent to hexane (about $15 \mathrm{ml}$ ) and then continued to concentrate on $1 \mathrm{ml}$. The silica column filled with anhydrous sodium sulfate, aluminum oxide and silica gel particles from top to bottom was used to clean the concentrated solution by hexane and then a mixed solvent ( $n$-hexane and DCM 7/3 (v/v), $70 \mathrm{ml}$ ) (Qiao et al., 2006). The eluate of the mixed solvent was recovered and concentrated by purging with ultra-pure nitrogen until near dryness. Subsequently, the eluate was diluted by $n$-hexane to $1 \mathrm{ml}$ for GC-MS analysis. The residue and QFFs were also extracted, cleaned and concentrated according to the same process.

Identification and quantification of PAHs were performed by GC-MS (GC model Agilent 6890 and MS model 5793) using a DB-5MS Agilent column $(30 \mathrm{~m} \times 0.25 \mathrm{~mm} \times 0.25 \mu \mathrm{m})$. The conditions for analysis were as follows: the carrier gas was He $(1 \mathrm{ml} / \mathrm{min})$; the injector temperature was $280{ }^{\circ} \mathrm{C}$ with splitless injection of $1 \mu \mathrm{l}$; the temperature program for GC oven was holding for $2 \mathrm{~min}$ at $50{ }^{\circ} \mathrm{C}$, then heating to $300{ }^{\circ} \mathrm{C}$ with the heating rate of $6{ }^{\circ} \mathrm{C} / \mathrm{min}$ and holding at $300{ }^{\circ} \mathrm{C}$ for $5 \mathrm{~min}$. External standard calibration was used for the quantification of 16 priority PAHs characterized by US EPA (shown in Table S1). The limits of detection of 16 PAHs were $0.05 \mathrm{ng} / \mathrm{g}$.

Table 2 presented the toxic equivalent factor (TEF) representing the toxicity of individual PAHs (Dai et al., 2014; Han et al., 2012; Nisbet, 1992). In this study, the toxicity equivalent value (TEQ) was adopted to evaluate the toxicity of the total PAHs, which was calculated by multiplying the TEF by the amounts of the corresponding PAHs (Liu et al., 2012).

\subsection{Quality assurance and control}

All solvents were HPLC grade. All glassware was soaked in a mixture solution (potassium bichromate and sulfuric acid) and then cleaned using an ultrasonic cleaner. Before sampling, XAD-2 was extracted in a Soxhlet extractor with DCM for $24 \mathrm{~h}$. QFFs and sodium sulfate were baked at $450{ }^{\circ} \mathrm{C}$ for $6 \mathrm{~h}$. The silica gel and alumina were soaked in the mixture of acetone: hexane (1:1) by ultrasonic extraction for $30 \mathrm{~min}$, followed by baked at $180^{\circ} \mathrm{C}$ and $250{ }^{\circ} \mathrm{C}$ for $12 \mathrm{~h}$, respectively and finally deactivated with $3 \%$ deionized water.

All experiments were conducted in triplicate to ensure the reproducibility and precision. The recoveries of surrogate standards for PAHs

\section{Table 2}

The distribution of PAHs in flue gas, fly ash and bottom ash from coal combustion alone at different temperatures.

\begin{tabular}{llrrrrr}
\hline PAHs & $500{ }^{\circ} \mathrm{C}$ & $600{ }^{\circ} \mathrm{C}$ & $700{ }^{\circ} \mathrm{C}$ & $800{ }^{\circ} \mathrm{C}$ & $900{ }^{\circ} \mathrm{C}$ \\
\hline \multirow{2}{*}{ 2-ring PAHs } & Flue gas $(\mu \mathrm{g} / \mathrm{g})$ & 54.89 & 69.54 & 103.65 & 143.25 & 66.68 \\
& Fly ash $(\mu \mathrm{g} / \mathrm{g})$ & 0.26 & 0.60 & 4.02 & 0.07 & 0.42 \\
& Bottom $\mathrm{ash}(\mu \mathrm{g} / \mathrm{g})$ & 3.83 & 0.52 & 0.47 & 0.10 & 0.02 \\
3-ring PAHs & Flue gas $(\mu \mathrm{g} / \mathrm{g})$ & 51.27 & 220.20 & 322.41 & 1384.48 & 1961.30 \\
& Fly ash $(\mu \mathrm{g} / \mathrm{g})$ & 9.87 & 9.28 & 11.68 & 2.19 & 11.13 \\
& Bottom $\mathrm{ash}(\mu \mathrm{g} / \mathrm{g})$ & 6.02 & 9.23 & 11.01 & 0.76 & 0.63 \\
4-ring PAHs & Flue gas $(\mu \mathrm{g} / \mathrm{g})$ & 24.05 & 13.13 & 15.69 & 720.23 & 1039.64 \\
& Fly ash $(\mu \mathrm{g} / \mathrm{g})$ & 10.70 & 6.58 & 7.19 & 16.45 & 41.57 \\
& Bottom $\mathrm{ash}(\mu \mathrm{g} / \mathrm{g})$ & 6.13 & 4.24 & 5.41 & 0.31 & 0.45 \\
5-ring PAHs & Flue gas $(\mu \mathrm{g} / \mathrm{g})$ & 14.42 & 98.96 & 835.46 & 100.10 & 235.80 \\
& Fly ash $(\mu \mathrm{g} / \mathrm{g})$ & 22.77 & 64.57 & 143.16 & 574.63 & 1397.05 \\
& Bottom $\mathrm{ash}(\mu \mathrm{g} / \mathrm{g})$ & 0.15 & 0.14 & 0.44 & 0.28 & 0.16 \\
6-ring PAHs & Flue gas $(\mu \mathrm{g} / \mathrm{g})$ & 0.55 & 0.10 & 0.07 & 12.70 & 113.82 \\
& Fly ash $(\mu \mathrm{g} / \mathrm{g})$ & 4.21 & 0.19 & 2.07 & 23.68 & 102.31 \\
& Bottom $\mathrm{ash}(\mu \mathrm{g} / \mathrm{g})$ & 0.39 & 0.05 & 0.08 & 0.02 & 0.15 \\
\multirow{2}{*}{ Total PAHs } & Flue gas $(\mu \mathrm{g} / \mathrm{g})$ & 132.29 & 303.21 & 442.10 & 2456.55 & 3375.86 \\
& Fly ash $(\mu \mathrm{g} / \mathrm{g})$ & 31.48 & 20.71 & 34.02 & 97.86 & 239.66 \\
& Bottom $\mathrm{ash}(\mu \mathrm{g} / \mathrm{g})$ & 17.20 & 14.16 & 17.11 & 1.26 & 1.43 \\
\hline
\end{tabular}

were in the range of $67.61 \%-132.84 \%$ for flue gas, $67.09 \%-126.87 \%$ for fly ash and $71.21 \%-122.95 \%$ for bottom ash, respectively.

\section{Results and discussion}

\subsection{PAH emissions during coal and MSW combustion alone}

\subsubsection{PAH emissions during coal combustion alone}

Fig. 1 displayed the effect of combustion temperature on total PAH emissions during coal combustion. As shown in Fig. 1, the total PAH emissions increased along with the increasing temperature (ranging from $179.57 \mu \mathrm{g} / \mathrm{g}$ at $500{ }^{\circ} \mathrm{C}$ to $3616.96 \mu \mathrm{g} / \mathrm{g}$ at $900{ }^{\circ} \mathrm{C}$ ). This observation was different from a previous study, in which it was reported that the peak yields of PAHs occurred at $800{ }^{\circ} \mathrm{C}$ and the total PAH yields decreased at temperatures above $800{ }^{\circ} \mathrm{C}$ during coal combustion (Liu et al., 2012). This is perhaps originated from the big difference of the coal samples used for the combustion experiments. It is well known that coal is a complicated heterogeneous material containing organic maceral and inorganic matters. Meanwhile, many studies had confirmed that PAH formations were strongly dependent on the maceral composition and coal's origin (Laumann et al., 2011). In addition, PAH yields from coal combustion slightly increased from $500{ }^{\circ} \mathrm{C}$ to $700{ }^{\circ} \mathrm{C}$ and then exhibited a rapid growth above $700{ }^{\circ} \mathrm{C}$. For instance, PAH yield at $800{ }^{\circ} \mathrm{C}(2555.66 \mu \mathrm{g} / \mathrm{g})$ was more than 5 times higher than that at $700{ }^{\circ} \mathrm{C}(493.22 \mu \mathrm{g} / \mathrm{g})$. This trend could be explained by PAH formation mechanism: pyro-synthesis. It is generally known that pyro-synthesis of 16 PAHs are endothermic reaction. Accordingly, these pyro-synthesis reactions increased at higher temperatures (Mastral and Callén, 2000). Therefore, more PAHs were generated at high temperatures resulting in rapid growth above $700{ }^{\circ} \mathrm{C}$.

In the individual PAHs, 16 PAHs peaked at a specific temperature. Ace peaked at $700{ }^{\circ} \mathrm{C}$; Nap, Fla, Chr and Bap at $800{ }^{\circ} \mathrm{C}$ and the others at $900{ }^{\circ} \mathrm{C}$, respectively (shown in Fig. S2). The most abundant PAH identified was Nap, which reached $32.85 \%$ of total PAHs at $500^{\circ} \mathrm{C}$, followed by Phe and Fla (29.39\% and $10.71 \%$, respectively). As for $600{ }^{\circ} \mathrm{C}$ and $700{ }^{\circ} \mathrm{C}$, the main compounds were Ant, Nap and Phe, while the major contribution was originated from Ant, Phe and Fla when the temperature increased from $800{ }^{\circ} \mathrm{C}$ to $900{ }^{\circ} \mathrm{C}$.

When 16 PAHs were classified by their ring number, the 3-ring PAHs were predominant at all examined temperatures and its yield showed monotone increasing trend with the increasing temperature from $67.16 \mu \mathrm{g} / \mathrm{g}$ at $500{ }^{\circ} \mathrm{C}$ to $1387.43 \mu \mathrm{g} / \mathrm{g}$ at $700{ }^{\circ} \mathrm{C}$ during coal combustion (shown in Fig. 2A). The PAHs were classified into three groups: low molar weight PAHs (LMW PAHs, 2- and 3-ring PAHs), middle molar weight (MMW, 4-ring PAHs) and high molar weight (HMW, 5- and 6-

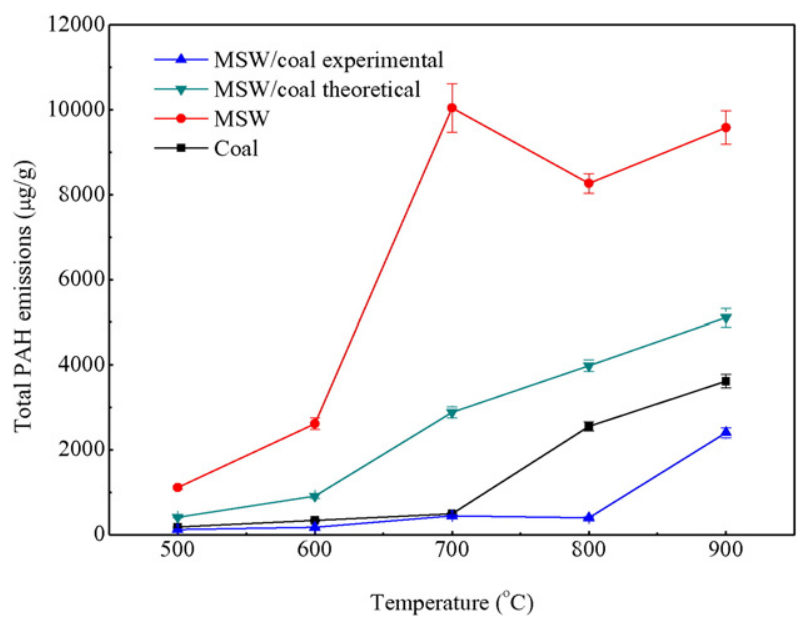

Fig. 1. The effect of temperature on total PAH emissions during MSW and coal combustion alone and their co-combustion. 

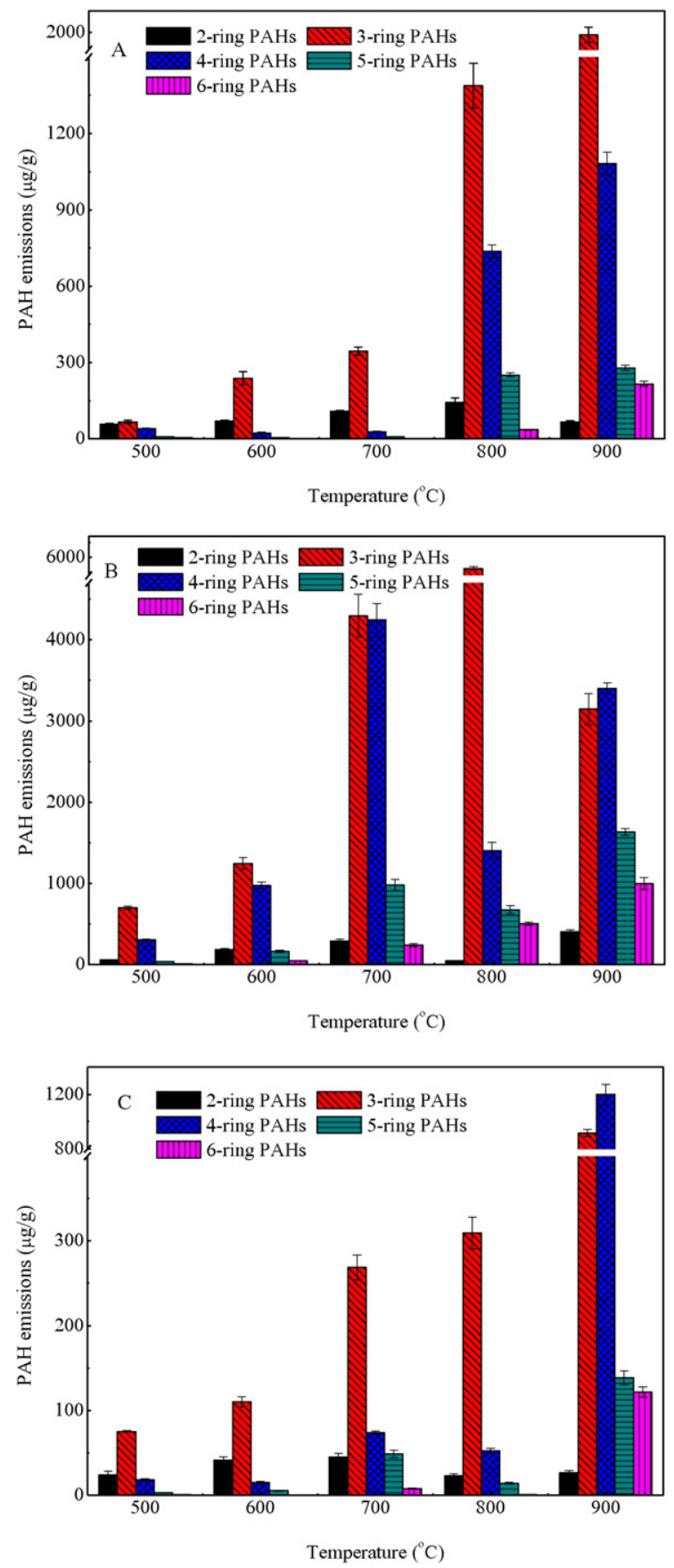

Fig. 2. The ring PAHs at different temperatures during coal combustion (A), MSW combustion (B) and MSW/coal co-combustion (C).

ring PAHs). The proportions of LMW, MMW and HMW were presented in Fig. 3 and the results showed that LMW PAH yields firstly increased until the temperate reached $700{ }^{\circ} \mathrm{C}$ (from $69.70 \%$ to $91.89 \%$ ) and then decreased with the increasing temperature from $800{ }^{\circ} \mathrm{C}$ to $900{ }^{\circ} \mathrm{C}$ (from 59.90\% to 56.40\%), suggesting that LMW PAHs accounted for main proportions at all examined temperatures during coal combustion. It is generally known that some low molecular compounds are bonded to coal macromolecular structure by means of weak bonds: hydrogen bonds and Van Der Waals forces (Liu et al., 2012). The weak bonds in coal began to rupture at low temperature and some PAHs were formed resulting in an increase of the LMW PAHs. On the other hand, the cyclization reaction of LMW PAHs during pyro-synthesis increased with the increasing temperature leading to the reduction of LMW PAH yields (Mastral and Callén, 2000). Different from LMW PAHs, the MMW and
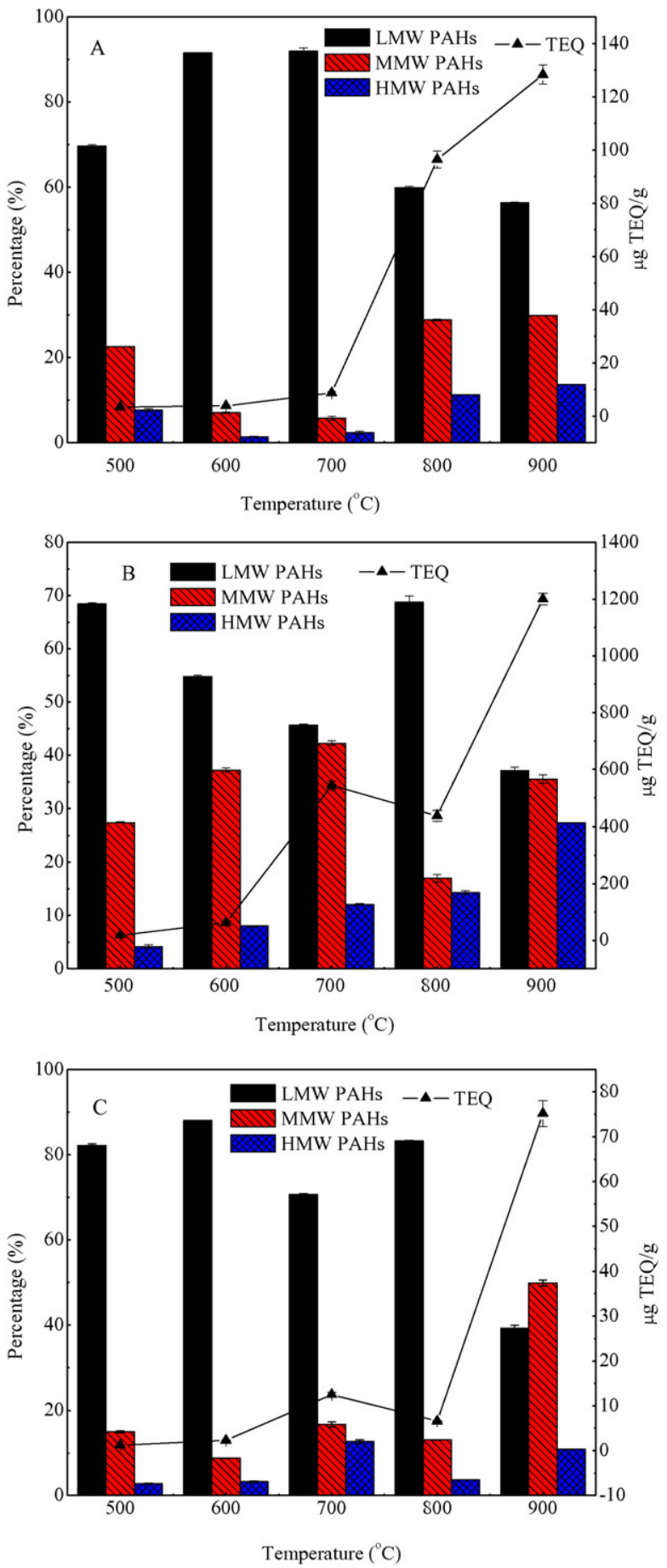

Fig. 3. The proportions of LMW, HMW MMW and PAHs and TEQ at different temperatures during coal combustion (A), MSW combustion (B) and MSW/coal co-combustion (C).

HMW PAHs decreased with the increasing temperature (from $22.59 \%$ at $500{ }^{\circ} \mathrm{C}$ to $5.74 \%$ at $700{ }^{\circ} \mathrm{C}$ for MMW PAHs and from $7.71 \%$ at $500{ }^{\circ} \mathrm{C}$ to $1.41 \%$ at $600{ }^{\circ} \mathrm{C}$ for HMW PAHs) and then increased up to $900{ }^{\circ} \mathrm{C}$ reaching a maximum value (29.91\% for MMW PAHs and $13.69 \%$ for HMW PAHs). The decomposition and formation of MMW and HMW PAHs co-exist and they are competitive reactions during coal combustion. This trend implied that the reaction of MMW and HMW PAHs was dominated by decomposition reaction at lower temperature and formation reaction at higher temperature, respectively. The Fig. 3A showed that the TEQ increased along with the increasing temperature from $3.39 \mu \mathrm{g} \mathrm{TEQ} / \mathrm{g}$ at $500{ }^{\circ} \mathrm{C}$ to $128.26 \mu \mathrm{g} \mathrm{TEQ} / \mathrm{g}$ at $900{ }^{\circ} \mathrm{C}$. The yields of Nap, Ace, Flu, Acy, Ant and Phe accounted for the majority of 16 
PAHs but Bap dominantly contributed to TEQ at examined temperatures.

Table 2 listed the distribution of PAHs in flue gas, fly ash and bottom ash during coal combustion. The PAH yields in the flue gas were the highest, followed by fly ash and bottom ash at all examined temperatures. The differences of PAH yields between flue gas, fly ash and bottom ash reached 1-3 orders of magnitudes during coal combustion. For example, PAH yield in flue gas was $3375.86 \mu \mathrm{g} / \mathrm{g}$, which was higher than that in fly ash and bottom ash $(239.66 \mu \mathrm{g} / \mathrm{g}$ and $1.43 \mu \mathrm{g} / \mathrm{g}$, respectively) at $900{ }^{\circ} \mathrm{C}$. In addition, the PAHs in flue gas were dominated by 2-ring PAHs at $500{ }^{\circ} \mathrm{C}$ while 3 -ring PAHs accounted for the majority at the temperature range of $600{ }^{\circ} \mathrm{C}$ to $900{ }^{\circ} \mathrm{C}$. Compared to flue gas, more high-ring PAHs were present in fly ash, especially at high temperatures (mainly 5and 6-ring PAHs at $800{ }^{\circ} \mathrm{C}$ and $900{ }^{\circ} \mathrm{C}$, respectively). In the case of bottom ash, 4-ring PAHs had the highest amounts at $500{ }^{\circ} \mathrm{C}$ and 3-ring PAHs was dominated at $600{ }^{\circ} \mathrm{C}-900{ }^{\circ} \mathrm{C}$.

\subsubsection{PAH emissions during MSW combustion alone}

As shown in Fig.1, the total PAH yields generated firstly increased with the increasing temperature until $700{ }^{\circ} \mathrm{C}$ reaching a maximum $(10,047.22 \mu \mathrm{g} / \mathrm{g})$ and then decreased to $8267.87 \mu \mathrm{g} / \mathrm{g}$ at $800^{\circ} \mathrm{C}$, followed by a slight increase to $9581.96 \mu \mathrm{g} / \mathrm{g}$ at $900{ }^{\circ} \mathrm{C}$. Compared to coal combustion, MSW combustion produced more total PAHs, equivalently more than twice the amount from coal combustion at all examined temperatures. The biggest difference of PAHs was observed at $700{ }^{\circ} \mathrm{C}$ and the PAH yields were $10,047.22 \mu \mathrm{g} / \mathrm{g}$ for MSW and $493.22 \mu \mathrm{g} / \mathrm{g}$ for coal, respectively. The higher PAH emissions were partly ascribed to high volatiles content of MSW. It was reported that the volatile compounds were the potential PAHs precursors and PAH emissions increased with the increasing volatile content during fuel combustion (Zhang et al., 2007). As shown in Table 1, the volatile matter in MSW was much higher than that in coal ( $86.94 \%$ for MSW and $26.43 \%$ for coal, respectively). In addition, free radicals like $\bullet \mathrm{OH}$ generated from the decomposition of water plays a positive role in PAH formation during MSW combustion (Chen et al., 2013). Therefore, the moisture content of MSW also contributed to high PAH emissions during MSW combustion.

In the 16 individual PAHs during MSW combustion, Ace, Pyr, BkF, $\mathrm{BaP}$ and IcP peaked at $900^{\circ} \mathrm{C}$; Ant, DaA and BgP at $800^{\circ} \mathrm{C}$ and the others at $700{ }^{\circ} \mathrm{C}$ (shown in Fig. S2B). The dominating PAH compounds were Phe, Chr and Fla at $500{ }^{\circ} \mathrm{C}$ and $600{ }^{\circ} \mathrm{C}$. At $800{ }^{\circ} \mathrm{C}$, Ant, Phe and Fla accounted for $47.67 \%, 18.34 \%$ and $6.34 \%$ of total PAHs, respectively. As for $700{ }^{\circ} \mathrm{C}$ and $900{ }^{\circ} \mathrm{C}$, Phe and Pyr were the highest abundant individual PAHs. When PAHs were classified by their ring number, the 3-ring PAHs were the main PAHs (from $42.75 \%$ to $68.17 \%$ of total PAHs) at the temperature from $500{ }^{\circ} \mathrm{C}$ to $800{ }^{\circ} \mathrm{C}$ during MSW combustion (shown in Fig. 2B) and 4-ring PAHs was dominated (35.51\%) at $900{ }^{\circ} \mathrm{C}$.

The proportions of LMW, MMW and HMW PAHs during MSW combustion were present in Fig. $3 \mathrm{~B}$ and it was showed that the proportions of LMW PAHs firstly decreased until the temperature reached $700{ }^{\circ} \mathrm{C}$ and then increased at $800{ }^{\circ} \mathrm{C}$, followed by a slight decrease up to $900{ }^{\circ} \mathrm{C}$. The MMW PAHs exhibited the opposite trend as that of LMW PAHs. The proportions of HMW PAHs increased with the increasing temperature from $500{ }^{\circ} \mathrm{C}$ to $900{ }^{\circ} \mathrm{C}$. Compared to coal combustion, the proportions of HMW and MMW PAHs from MSW combustion were high, except for MMW PAHs at $800^{\circ} \mathrm{C}$. For instance, the largest difference between coal and MSW combustion was up to 36.52\% for MMW PAHs at $700{ }^{\circ} \mathrm{C}$ and $13.74 \%$ for HMW PAHs at $900{ }^{\circ} \mathrm{C}$, respectively. The high proportions of HMW and MMW PAHs from MSW combustion was possibly related to the hydrogen abstraction acetylene addition (HACA) reaction. It was reported the HACA played a minor role for PAH formations during coal combustion (Liu et al., 2012) while it was the main PAHs information mechanism during plastics combustion, especially for HMW PAHs (You, 2008). Considering the high proportion of plastics in MSW, HACA was responsible for the high yields of MMW and HMW PAHs from MSW combustion. Meanwhile, the high proportions of HMW and MMW PAHs indicated that MSW combustion generated much high toxic PAHs compared to coal combustion. TEQ profile was shown in Fig. 3B and it presented a similar trend to the total PAHs with the range from $18.29 \mu \mathrm{g} \mathrm{TEQ} / \mathrm{g}$ at $500{ }^{\circ} \mathrm{C}$ to $1199.91 \mu \mathrm{g} \mathrm{TEQ} / \mathrm{g}$ at $900{ }^{\circ} \mathrm{C}$. It was worthily to note that Ant, Pyr, Phe, Chr and Fla accounted for the majority of 16 PAHs while Bap was the major contribution to TEQ at most temperatures. Compared to coal combustion, the toxicity of PAHs were much higher due to high TEQ at examined temperatures during MSW combustion, which was in good agreement with the above analysis of LMW, HMW and MMW PAHs.

Table 3 illustrated the distribution of PAH emissions in flue gas, fly ash and bottom ash during MSW combustion and the results showed that the distribution of total PAHs was consistent with coal combustion. Compared to coal combustion, the total PAHs from MSW combustion were significantly high in flue gas and fly ash while the PAHs in bottom ash were low, except for that at $800{ }^{\circ} \mathrm{C}$. The 3-ring PAHs occupied the highest proportion of total PAHs in flue gas and bottom ash, except for bottom ash at $800^{\circ} \mathrm{C}$, while the main proportion in fly ash was 4-ring PAHs, except for $800{ }^{\circ} \mathrm{C}$ (mainly 5-ring PAHs). The high proportions of MMW and HMW PAHs in fly ash indicated that the MMW and HMW PAHs considerably tend to accumulate on the airborne particles in comparison with the LMW PAHs. This observation was probably arisen from the fact that LMW PAHs were easier to be volatilized from particles into the gas phase because of their high saturated vapor pressure.

\subsection{PAH emissions during MSW/coal co-combustion}

For MSW/coal co-combustion, the trend of total PAHs against combustion temperature was similar to that from MSW combustion, which ranged from $120.49 \mu \mathrm{g} / \mathrm{g}$ to $2402.17 \mu \mathrm{g} / \mathrm{g}$ ( shown in Fig. 1). Compared to coal and MSW combustion alone, MSW/coal co-combustion produced the least amount of total PAHs. It exhibited a different trend from the study in which the total PAH yields decreased in the order MSW $>$ MSW/coal $>$ coal (You, 2008). Regarding the distribution of 16 PAHs, Nap, Acy and Ace peaked at $700{ }^{\circ} \mathrm{C}$; Ant peaked at $800{ }^{\circ} \mathrm{C}$ and others peaked at $900{ }^{\circ} \mathrm{C}$ from MSW/coal co-combustion, which was moderately similar to that from coal combustion alone (shown in Fig. S2C). Among those PAHs, Ant, Phe and Nap were the dominating individual PAHs at the temperature range of $500{ }^{\circ} \mathrm{C}-800{ }^{\circ} \mathrm{C}$. While at $900^{\circ}$ $\mathrm{C}$, the most abundant species of individual PAHs was Phe, which reached $752.63 \mu \mathrm{g} / \mathrm{g}$, followed by Pyr and Fla $(545.16 \mu \mathrm{g} / \mathrm{g}$ and $372.14 \mu \mathrm{g} / \mathrm{g}$, respectively). In addition, as shown in Fig. 2C, 3-ring PAHs were the main constituents of PAHs at the temperature ranging from $500{ }^{\circ} \mathrm{C}$ to $800{ }^{\circ} \mathrm{C}$ and 4-ring PAHs was dominated at $900{ }^{\circ} \mathrm{C}$. As for the proportions of LMW, MMW and HMW PAHs (shown in Fig. 3C), a major contribution originated from the LMW PAHs with the

Table 3

The distribution of PAHs in flue gas, fly ash and bottom ash from MS combustion alone at different temperatures.

\begin{tabular}{llrrrrr}
\hline PAHs & $500{ }^{\circ} \mathrm{C}$ & $600{ }^{\circ} \mathrm{C}$ & $700{ }^{\circ} \mathrm{C}$ & $800{ }^{\circ} \mathrm{C}$ & $900{ }^{\circ} \mathrm{C}$ \\
\hline 2-ring PAHs & Flue gas $(\mu \mathrm{g} / \mathrm{g})$ & 57.32 & 184.02 & 288.11 & 43.42 & 400.03 \\
& Fly ash $(\mu \mathrm{g} / \mathrm{g})$ & 0.09 & 0.65 & 0.06 & 0.42 & 4.09 \\
& Bottom ash $(\mu \mathrm{g} / \mathrm{g})$ & 0.50 & 1.18 & 0.55 & 3.02 & 0.01 \\
3-ring PAHs & Flue gas $(\mu \mathrm{g} / \mathrm{g})$ & 671.81 & 1221.61 & 4283.74 & 5619.32 & 3078.92 \\
& Fly ash $(\mu \mathrm{g} / \mathrm{g})$ & 16.96 & 16.00 & 7.15 & 14.78 & 67.12 \\
& Bottom ash $(\mu \mathrm{g} / \mathrm{g})$ & 13.37 & 8.93 & 4.10 & 1.75 & 0.66 \\
4-ring PAHs & Flue gas $(\mu \mathrm{g} / \mathrm{g})$ & 225.51 & 783.83 & 4040.61 & 1110.20 & 2002.36 \\
& Fly ash $(\mu \mathrm{g} / \mathrm{g})$ & 77.88 & 189.66 & 202.45 & 294.71 & 1399.78 \\
& Bottom ash $(\mu \mathrm{g} / \mathrm{g})$ & 1.77 & 0.65 & 3.27 & 0.68 & 0.33 \\
5-ring PAHs & Flue gas $(\mu \mathrm{g} / \mathrm{g})$ & 14.42 & 98.96 & 835.46 & 100.10 & 235.80 \\
& Fly ash $(\mu \mathrm{g} / \mathrm{g})$ & 22.77 & 64.57 & 143.16 & 574.63 & 1397.05 \\
& Bottom ash $(\mu \mathrm{g} / \mathrm{g})$ & 0.15 & 0.14 & 0.44 & 0.28 & 0.16 \\
6-ring PAHs & Flue gas $(\mu \mathrm{g} / \mathrm{g})$ & 3.36 & 30.64 & 201.27 & 0.40 & 119.15 \\
& Fly ash $(\mu \mathrm{g} / \mathrm{g})$ & 5.27 & 15.94 & 36.60 & 504.04 & 876.46 \\
& Bottom ash $(\mu \mathrm{g} / \mathrm{g})$ & 0.11 & 0.07 & 0.25 & 0.12 & 0.04 \\
Total PAHs & Flue gas $(\mu \mathrm{g} / \mathrm{g})$ & 972.42 & 2319.06 & 9649.19 & 6873.44 & 5836.26 \\
& Fly ash $(\mu \mathrm{g} / \mathrm{g})$ & 122.97 & 286.82 & 389.42 & 1388.58 & 3744.50 \\
& Bottom ash $(\mu \mathrm{g} / \mathrm{g})$ & 15.90 & 10.97 & 8.61 & 5.85 & 1.20 \\
\hline
\end{tabular}


temperature range of $500{ }^{\circ} \mathrm{C}$ to $800{ }^{\circ} \mathrm{C}$ (from $70.66 \%$ to $87.99 \%$ ) and MMW PAHs at $900{ }^{\circ} \mathrm{C}(49.89 \%)$. Fig. $3 \mathrm{C}$ also showed the TEQ profile from MSW/coal co-combustion and its trend was similar to that from MSW combustion. However, the TEQ (from $1.24 \mu \mathrm{g}$ TEQ/g to $75.19 \mu \mathrm{g}$ $\mathrm{TEQ} / \mathrm{g}$ ) was much lower than that from coal and MSW combustion alone. The BaP played an important role in TEQ from $600{ }^{\circ} \mathrm{C}$ to $900{ }^{\circ} \mathrm{C}$, except for Ant at $500{ }^{\circ} \mathrm{C}$.

The distribution of PAH emissions in flue gas, fly ash and bottom ash during MSW/coal co-combustion was provided in Table 4. The total PAHs in flue gas were the highest, followed by fly ash and bottom ash at all examined temperatures. By comparing with coal and MSW combustion alone, the total PAHs in flue gas, fly ash and bottom ash were lowest at most examined temperatures during MSW/coal co-combustion. On the basis of ring number, 3-ring PAHs was higher than other ring PAHs in flue gas and bottom ash, except for flue gas at $900{ }^{\circ} \mathrm{C}$ (mainly 4-ring PAHs). The 4-ring PAHs in fly ash accounted for the majority of PAHs as the temperature from $500{ }^{\circ} \mathrm{C}$ to $800{ }^{\circ} \mathrm{C}$ and 6-ring PAHs occupied the dominant proportion at $900{ }^{\circ} \mathrm{C}$. It was clear that the yields of high ring number PAHs in fly ash were much higher than those in flue gas and bottom ash from MSW/coal co-combustion, showing a similar pattern to MSW and coal combustion alone.

\subsection{Effect of the blending of coal and MSW on PAH emissions}

In order to investigate the effect of the blending of coal and MSW on $\mathrm{PAH}$ emissions, the theoretical values of total PAH emissions were also calculated as follows:

Yield $_{\text {blend }}=$ Yieldcoal $\times 0.75+$ YieldMSW $\times 0.25$

As shown in Fig. 1, the theoretical values of total PAHs were from $412.50 \mu \mathrm{g} / \mathrm{g}$ to $5108.21 \mu \mathrm{g} / \mathrm{g}$, which were much higher than the experimental values at all examined temperatures. The theoretical proportions of LMW, MMW and HMW PAHs were calculated according to Eq. (1) and the results were presented in Table S1. For the temperature of $500^{\circ} \mathrm{C}-800^{\circ} \mathrm{C}$, the experimental proportions of LMW PAHs were higher and the proportions of MMW and HMW PAHs were lower than that of the theoretical proportions. The LMW PAHs of experimental values increased by $13.40 \%, 22.98 \%, 19.10 \%$ and $18.81 \%$ from $500{ }^{\circ} \mathrm{C}$ to $800{ }^{\circ} \mathrm{C}$, respectively. Therefore, the toxicity of PAHs were lower due to the reduction of the highly toxic high-ring PAHs from MSW/coal co-combustion. At $900{ }^{\circ} \mathrm{C}$, the experimental proportion of HMW PAHs significantly reduced by $9.29 \%$ despite the smaller percent of LMW PAHs and higher percent of MMW PAHs. In order to analyze the toxicity of PAHs, the theoretical values of TEQ were also calculated by Eq. (1) and

Table 4

The distribution of PAHs in flue gas, fly ash and bottom ash from MSW/coal co-combustion at different temperatures.

\begin{tabular}{llrrrrr}
\hline PAHs & $500{ }^{\circ} \mathrm{C}$ & $600{ }^{\circ} \mathrm{C}$ & $700{ }^{\circ} \mathrm{C}$ & $800{ }^{\circ} \mathrm{C}$ & $900{ }^{\circ} \mathrm{C}$ \\
\hline \multirow{2}{*}{ 2-ring PAHs } & Flue gas $(\mu \mathrm{g} / \mathrm{g})$ & 21.37 & 41.27 & 44.44 & 22.73 & 25.28 \\
& Fly ash $(\mu \mathrm{g} / \mathrm{g})$ & 1.05 & 0.14 & 0.57 & 0.13 & 1.31 \\
& Bottom ash $(\mu \mathrm{g} / \mathrm{g})$ & 1.50 & 0.08 & 0.04 & 0.12 & 0.02 \\
3-ring PAHs & Flue gas $(\mu \mathrm{g} / \mathrm{g})$ & 67.26 & 108.10 & 257.97 & 285.27 & 884.58 \\
& Fly ash $(\mu \mathrm{g} / \mathrm{g})$ & 3.98 & 1.37 & 9.96 & 23.20 & 31.47 \\
& Bottom ash $(\mu \mathrm{g} / \mathrm{g})$ & 3.90 & 0.65 & 0.68 & 0.95 & 0.60 \\
4-ring PAHs & Flue gas $(\mu \mathrm{g} / \mathrm{g})$ & 5.39 & 9.62 & 15.24 & 9.25 & 1132.57 \\
& Fly ash $(\mu \mathrm{g} / \mathrm{g})$ & 12.03 & 5.17 & 58.60 & 42.58 & 65.80 \\
& Bottom ash $(\mu \mathrm{g} / \mathrm{g})$ & 0.64 & 0.32 & 0.21 & 0.34 & 0.18 \\
5-ring PAHs & Flue gas $(\mu \mathrm{g} / \mathrm{g})$ & 0.52 & 0.23 & 4.97 & 0.12 & 70.92 \\
& Fly ash $(\mu \mathrm{g} / \mathrm{g})$ & 2.27 & 5.16 & 43.43 & 13.25 & 67.72 \\
& Bottom $\mathrm{ash}(\mu \mathrm{g} / \mathrm{g})$ & 0.10 & 0.08 & 0.06 & 0.62 & 0.03 \\
6-ring PAHs & Flue gas $(\mu \mathrm{g} / \mathrm{g})$ & 0.06 & 0.03 & 2.08 & 0.14 & 37.52 \\
& Fly ash $(\mu \mathrm{g} / \mathrm{g})$ & 0.36 & 0.04 & 5.63 & 0.08 & 84.14 \\
& Bottom $\mathrm{ash}(\mu \mathrm{g} / \mathrm{g})$ & 0.05 & 0.03 & 0.02 & 0.32 & 0.02 \\
\multirow{2}{*}{ Total PAHs } & Flue gas $(\mu \mathrm{g} / \mathrm{g})$ & 94.60 & 159.25 & 324.70 & 317.51 & 2150.87 \\
& Fly ash $(\mu \mathrm{g} / \mathrm{g})$ & 19.69 & 11.88 & 118.19 & 79.24 & 250.44 \\
& Bottom ash $(\mu \mathrm{g} / \mathrm{g})$ & 6.19 & 1.16 & 1.01 & 2.34 & 0.85 \\
\hline
\end{tabular}

the results showed in Table S1. The TEQ increased with the increasing temperature from $7.11 \mu \mathrm{g}$ TEQ/g at $500{ }^{\circ} \mathrm{C}$ to $396.17 \mu \mathrm{g}$ TEQ/g at $900^{\circ}$ $\mathrm{C}$, which were much higher than the corresponding experimental values. The distribution of theoretical and experimental PAHs in flue gas, fly ash and bottom ash during MSW/coal combustion were shown in Table S2 and Table 4, respectively. Compared to the theoretical values, the experimental PAHs were low at all examined temperatures. For example, the PAH yield in flue gas was $317.52 \mu \mathrm{g} / \mathrm{g}$ at $800{ }^{\circ} \mathrm{C}$ and the corresponding theoretical value was $3560.78 \mu \mathrm{g} / \mathrm{g}$, between which the difference was about 10 times. The difference between theoretical and experimental PAHs suggested that the synergistic interactions between MSW and coal occurred during their co-combustion.

To further determine the interactions within MSW/coal blend, the percent change for the difference (PCD) between experimental and theoretical value of $\mathrm{PAH}$ yields at different temperatures were calculated as follows (Liu and Balasubramanian, 2014):

PCD $(\%)=\frac{\text { Experimental-Theoretical }}{\text { Theoretical }} \times 100$

Fig. 4 illustrated the deviations between theoretical and experimental values of total PAHs and TEQ from MSW/coal co-combustion. The PCD values were all negative in this study, indicating that the blending of MSW and coal decreased the PAH emissions. The absolute PCD values of total PAHs increased from $70.79 \%$ to $89.98 \%$ with the increasing
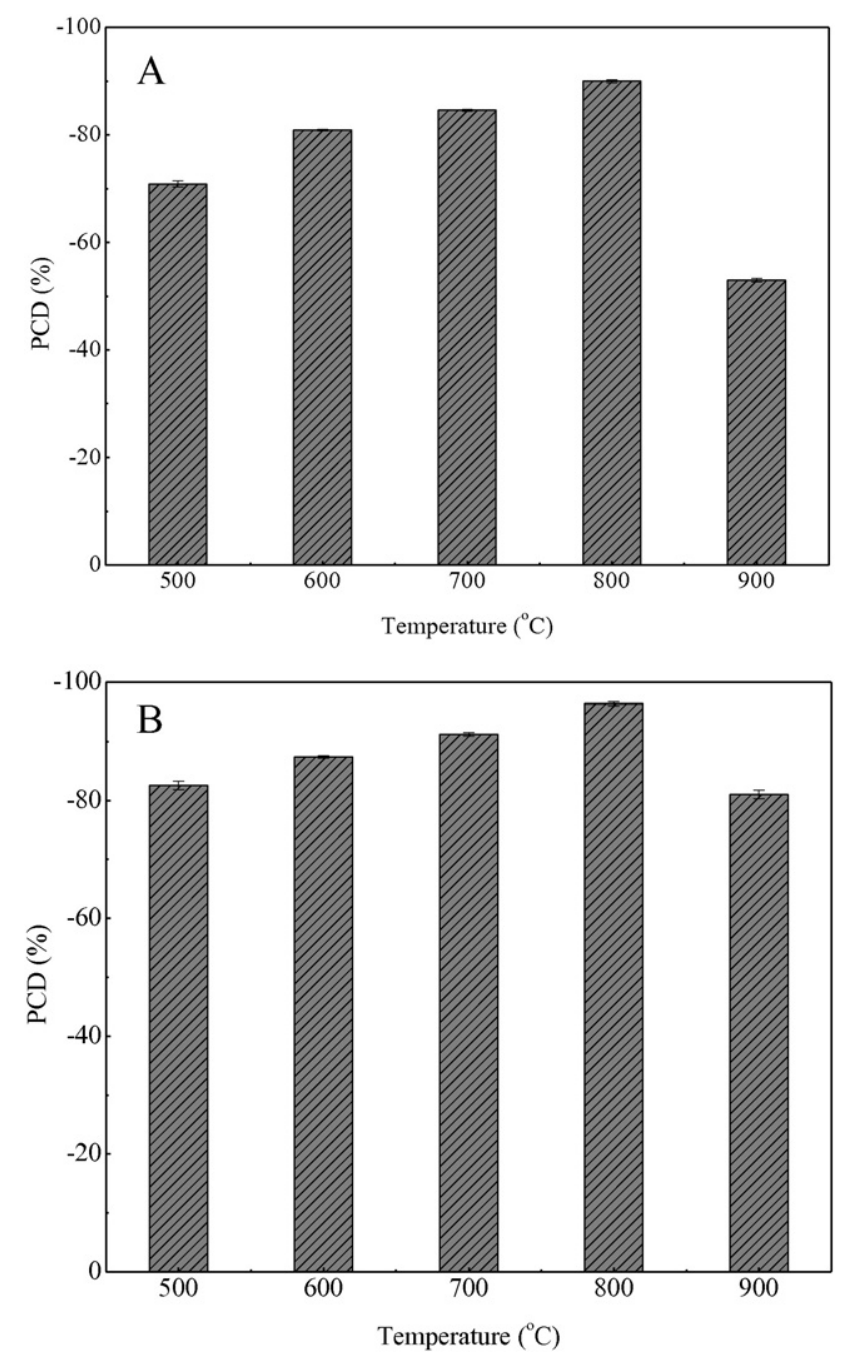

Fig. 4. The deviations between theoretical and experimental values of total PAHs (A) and TEQ (B) during MSW/coal co-combustion. 
temperature from $500{ }^{\circ} \mathrm{C}$ to $800{ }^{\circ} \mathrm{C}$ and then reduced up to $52.97 \%$ at $900{ }^{\circ} \mathrm{C}$, implying that more significant interactions occurred at $800{ }^{\circ} \mathrm{C}$ (shown in Fig. 4A). The PCD of TEQ was shown in Fig. 4B and the results showed that the absolute PCD values increased with the increasing temperature reaching a maximum at $96.38 \%$ at $800{ }^{\circ} \mathrm{C}$ and then decreased to $81.02 \%$. The similar pattern of total PAHs and TEQ tendency implied that co-combustion of coal and MSW drastically reduced the yield and toxicity of PAHs, especially at $800{ }^{\circ} \mathrm{C}$. In addition, the absolute PCD values of TEQ were higher than that of total PAHs, suggesting that the coal and $\mathrm{MSW} /$ coal co-combustion was more efficient to reduce the toxicity of $\mathrm{PAH}$ emissions than total PAH yields.

The above analysis confirmed that the synergistic interactions occurred between coal and MSW during co-combustion. MSW and coal co-combustion not only suppressed the formation of PAHs, especially for high-ring PAHs, but also reduced the toxicity of PAH emissions.

\section{Conclusions}

PAH emissions during coal and MSW combustion alone and their cocombustion have been investigated in the present study. It was found that the highest yields of total PAHs were generated from MSW combustion, followed by coal combustion and MSW/coal co-combustion at all examined temperatures. Higher temperature favored the formation of PAHs and the 3- and 4-ring PAHs were dominant in total PAHs. On the basis of the distribution, the formed PAHs were primarily present in the flue gas, and fly ash contained more high-ring PAHs than bottom ash and flue gas. The toxicity of PAHs from MSW/coal co-combustion was much lower than that during coal and MSW combustion alone. Synergistic interactions occurred between MSW and coal during co-combustion, resulting in significantly suppressed formation of PAHs, especially for highly toxic high-ring PAHs. The present study indicated that reducing PAH emissions and toxicity can be achieved by MSW and coal co-combustion.

\section{Acknowledgement}

The authors gratefully acknowledge financial support for Zhengang Liu from the "100 Talents" Program of the Chinese Academy of Sciences and the Beijing Natural Sciences Foundation, China (Project No. 3142020).

\section{Appendix A. Supplementary data}

Supplementary data to this article can be found online at http://dx. doi.org/10.1016/j.scitotenv.2016.05.188.

\section{References}

Chen, Y., Zhao, R., Xue, J., Li, J., 2013. Generation and distribution of PAHs in the process of medical waste incineration. Waste Manag. 33, 1165-1173.

Cheng, H., Hu, Y., 2010. Municipal solid waste (MSW) as a renewable source of energy: current and future practices in China. Bioresour. Technol. 101, 3816-3824.

Dai, Q., Jiang, X., Jiang, Y., Jin, Y., Wang, F., Chi, Y., Yan, J.H., 2014. Formation of PAHs during the pyrolysis of dry sewage sludge. Fuel 130, 92-99.

Dong, J., Li, F., Xie, K., 2012. Study on the source of polycyclic aromatic hydrocarbons (PAHs) during coal pyrolysis by PY-GC-MS. J. Hazard. Mater. 243, 80-85.

Han, J., Qin, L.B., Ye, W., Li, Y.Q., Liu, L., Wang, H., Yao, H., 2012. Emission of polycyclic aromatic hydrocarbons from coal and sewage sludge co-combustion in a drop tube furnace. Waste Manage. Res. 30, 875-882.

Laumann, S., Micić, V., Kruge, M.A., Achten, C., Sachsenhofer, R.F., Schwarzbauer, J. Hofmann, T., 2011. Variations in concentrations and compositions of polycyclic aromatic hydrocarbons (PAHs) in coals related to the coal rank and origin. Environ. Pollut. 159, 2690-2697.

Liu, Z., Balasubramanian, R., 2014. A comparative study of nitrogen conversion during pyrolysis of coconut fiber, its corresponding biochar and their blends with lignite. Bioresour. Technol. 151, 85-90.
Liu, W.X., Dou, H., Wei, Z.C., Chang, B., Qiu, W.X Liu, Y., Tao, S., 2009. Emission characteristics of polycyclic aromatic hydrocarbons from combustion of different residential coals in North China. Sci. Total Environ. 407, 1436-1446.

Liu, S., Wang, C., Zhang, S., Liang, J., Chen, F., Zhao, K., 2012. Formation and distribution of polycyclic aromatic hydrocarbons (PAHs) derived from coal seam combustion: a case study of the Ulanqab lignite from Inner Mongolia, northern China. Int. J. Coal Geol. 9091, 126-134.

Liu, Z., Quek, A., Parshetti, G., Jain, A., Srinivasan, M.P., Hoekman, S.K., Balasubramanian, R., 2013. A study of nitrogen conversion and polycyclic aromatic hydrocarbon (PAH) emissions during hydrochar-lignite co-pyrolysis. Appl. Energy 108, 74-81.

Mastral, A.M., Callén, M.S., 2000. A review on polycyclic aromatic hydrocarbon (PAH) emissions from energy generation. Environ. Sci. Technol. 34, 3051-3057.

Mugica-Alvarez, V., Santiago-de la Rosa, N., Figueroa-Lara, J., Flores-Rodríguez, J., TorresRodríguez, M., Magaña-Reyes, M., 2015. Emissions of PAHs derived from sugarcane burning and processing in Chiapas and Morelos México. Sci. Total Environ. 527-528, 474-482.

Muthuraman, M., Namioka, T., Yoshikawa, K., 2010a. A comparative study on co-combustion performance of municipal solid waste and Indonesian coal with high ash Indian coal: a thermogravimetric analysis. Fuel Process. Technol. 91, 550-558.

Muthuraman, M., Namioka, T., Yoshikawa, K., 2010b. A comparison of co-combustion characteristics of coal with wood and hydrothermally treated municipal solid waste. Bioresour. Technol. 101, 2477-2482.

Nisbet, I., Lagoy, C.T., K., P., 1992. Toxic equivalency factors (TEFs) for polycyclic aromatic hydrocarbons (PAHs). Regul. Toxicol. Pharmacol. 16, 290-300.

Pongpiachan, S., Tipmanee, D., Khumsup, C., Kittikoon, I., Hirunyatrakul, P., 2015. Assessing risks to adults and preschool children posed by PM2.5-bound polycyclic aromatic hydrocarbons (PAHs) during a biomass burning episode in Northern Thailand. Sci. Total Environ. 508, 435-444.

Qiao, M., Wang, C., Huang, S., Wang, D., Wang, Z., 2006. Composition, sources, and potential toxicological significance of PAHs in the surface sediments of the Meiliang Bay, Taihu Lake. China. Environ. Int. 32, 28-33.

Ribeiro, J., Silva, T., Mendonca Filho, J.G., Flores, D., 2012. Polycyclic aromatic hydrocarbons (PAHs) in burning and non-burning coal waste piles. J. Hazard. Mater. 199200, 105-110.

Shen, C.F., Tang, X.J., Yao, J., Shi, D.Z., Fang, J., Khan, M.I., Cheema, S.A., Chen, Y.X., 2010. Levels and patterns of polycyclic aromatic hydrocarbons and polychlorinated biphenyls in municipal waste incinerator bottom ash in Zhejiang province, China. J. Hazard. Mater. 179, 197-202.

Singh, R.P., Tyagi, V.V., Allen, T., Ibrahim, M.H., Kothari, R., 2011. An overview for exploring the possibilities of energy generation from municipal solid waste (MSW) in Indian scenario. Renew. Sust. Energ. Rev. 15, 4797-4808.

Suksankraisorn, K., Patumsawad, S., Fungtammasan, B., 2010. Co-firing of Thai lignite and municipal solid waste (MSW) in a fluidised bed: effect of MSW moisture content. Appl. Therm. Eng. 30, 2693-2697.

Tian, H., Gao, J., Lu, L., Zhao, D., Cheng, K., Qiu, P., 2012. Temporal trends and spatial variation characteristics of hazardous air pollutant emission inventory from municipal solid waste incineration in China. Environ. Sci. Technol. 46, 10364-10371.

Tsai, J.H., Chen, S.J., Huang, K.L., Lin, Y.C., Lee, W.J., Lin, C.C., Lin, W.Y., 2010. PM, carbon, and PAH emissions from a diesel generator fuelled with soy-biodiesel blends. J. Hazard. Mater. 179, 237-243.

Verma, S.K., Masto, R.E., Gautam, S., Choudhury, D.P., Ram, L.C., Maiti, S.K., Maity, S., 2015. Investigations on PAHs and trace elements in coal and its combustion residues from a power plant. Fuel 162, 138-147.

Wang, R., Liu, G., Zhang, J., 2015. Variations of emission characterization of PAHs emitted from different utility boilers of coal-fired power plants and risk assessment related to atmospheric PAHs. Sci. Total Environ. 538, 180-190.

Xu, S., Liu, W., Tao, S., 2006. Emission of polycyclic aromatic hydrocarbons in China. Environ. Sci. Technol. 40, 702-708.

Yan, J.H., You, X.F., Li, X.D., Ni, M.J., Yin, X.F., Cen, K.F., 2004. Performance of PAHs emission from bituminous coal combustion. J. Zhejiang Univ. Sci. 5, 1554-1564.

You, X., 2008. Polycyclic aromatic hydrocarbon (PAH) emission from co-firing municipal solid waste (MSW) and coal in a fluidized bed incinerator. Waste Manag. 28, 1543-1551.

Yu, J., Sun, L., Ma, C., Qiao, Y., Yao, H., 2016. Thermal degradation of PVC: a review. Waste Management. 48, 300-314.

Zhang, Y., Tao, S., Cao, J., Coveney, R.M., 2007. Emission of polycyclic aromatic hydrocarbons in China by county. Environ. Sci. Technol. 41, 683-687.

Zhang, L., Su, X., Zhang, Z., Liu, S., Xiao, Y., Sun, M., Su, J.X., 2014. Characterization of fly ash from a circulating fluidized bed incinerator of municipal solid waste. Environ. Sci. Pollut. R. 21, 12767-12779.

Zhou, H., Long, Y., Meng, A, Li, Q Zhang Y. 2014. An overview of characteristics of municipal solid waste fuel in China: physical, chemical composition and heating value. Renew. Sust. Energ. Rev. 36, 107-122.

Zhou, H., Long, Y., Meng, A., Li, Q., Zhang, Y., 2015. Classification of municipal solid waste components for thermal conversion in waste-to-energy research. Fuel 145 , 151-1557. 